\title{
IR $48-2$
}

MINING OPERATIONS IN THE RAMPART DISTRICT, 1962

During September 21 to 26, 1962, I visited Rampart to obtain right-of-way easements for the Eureka-Rampart access road. Work at placer mines in the district had ceased for the year, but I obtained information about the mining operations Irom some of the miners. The number of active operations in the district remains about the same ats it was in 1960, but work done on the various properties in 1962 was almost entirely maintenance and preparatory work.

Harry Havrilack continued work on Ruby Creek but did only $K_{x}+B \cdot 20$ a small amount of sluicing during the year, devoting most of his time to strlpping and other preparatory work.

\section{Idaho Bar Mining Co., operated by Ace Parker and Kosta:}

Melinkoff, began a new operation in 1962 on Idaho Bar, which is on the top of a ridge between Little Minook Creek and Hunter Creek. The $K \times 18-33$ ridge is about 3000 feet higher than the mouths of the creeks. It is planned that water for mining will be pumped from the upper part of Little Minook Creek. The 1962 season was spent in preparatory work. T and Tining Co. dia not mine during the year. Bils $18-1^{05}$ Thomas, owner and operator of the company, worked on the property on weekends only, and his work consisted of stripping.

Brian MacDivitt mine $\alpha$ by hand on Minook Creek for a short $k \times 4847$ time during the 1962 season. He also spent a month in the early part of the surmer on a prospecting trip on which he covered a large part of the Hess Creok dratnage. 
Quail Creek Mining Co., owned and operated by Mel Haugdahl and Willie Redig, was reported to have mined during the season on quail $k \times 48-75$ Creek. This operation was described in a report in 1957, and, since then, the operation has been intermittent. When the omers are not mining, they work as electrieians in the Fairbanks area.

College, Alaska February, 1963
Robert $\mathrm{H}$. Saunders

State Mining Engineer 
MINING OPERATIONS IN THE NANLEY HOT SPRINGS

AND TOLOVANA. DISTRICTS, 1962

Durtng July 31 through August 3, 1962, I made a trip to Eureks to obtain right-of-way easements for the Eureka-Rampart access road, and, on the trip, I visited the fow placer mining operations that are still active in the Manley Hot Sprinds and Tolovana districts.

\section{Manley Hot Springs: District.}

Gus Benson was preparing to sink a prospect shaft on the $k \times 48-3$ right limit of Cache Creek on claims that he has owned for many years. Harold Strandberg was moving equipment from Eureka to Tofty and repairing a ditch at Tofty in preperation for mining there in 1963. $2 \times 48-44$ The Eureka Creek operation of Strandberg Mines, Inc., was idle, and some of the equipment was being offered for sale.

Rhode Island Creek Mines, owned and oporated by Archie Pringle, mined throughout the 1962 season on the left-limit bench of $k$ ít $48-.37$ Rhode Island Creek below the mouth of Gold Run. This is the area that was being stripped when the operation was visited in 1960. Two TD-18 tractors, a sluice plate, and steel sluice boxes are used for mining. The owner employs one man to help him run the operation. Tony Lanning mined one cut in the early part of the 1962

season at Shirley Bar. During the remainder of the season, he mined K K $458-25$ on the upper part of Eureka Creek on ground formerly owned by Pete Johnson but now owned by Pete's nephew, Leo C. Johnson, of South Pasadena, Callfornia, and leased by Tony。 On Eureka Creek, Tony mines alone using a TD-14 tractor and the same boxes and hydraulic equipment that Pete 
formerly used. Sluicing is done in "splashes", and the ditch is used for water storage. The boxes, wings, pipelines, giants, and the ditch are used in the same general mannor that Pete used them, however, Tony mines with the TD-14 and, therefore, is able to use all of the available water for siluicing. The boxes appeared to be in the same place as they are shown in the photograph in the 1960 report.

Tolovana District.

The Rëdstone Mining Company, owned and operated by Carl Heflinger, mined during 1962 on Livengood Creek near the mouth of

Gertrude Creek. Two D-8 tractors are used for stripping and mining, K/249-18 and an HD-14 tractor is used for stacking tailing. The ground averages 20 feet in depth: 15 feet of muck and 5 feet of gravel. The nuck and the upper two feet of gravel are stripped by bulldozers. Three cuts of 35,000 square feet eqch are mined in one season. Steel sluice boxes are used, on a grade of 18 inches per box length, and a sluice plate is used at the head of the boxes. This is a one-family operation with Caxl and his two sons doing all the work. k454.395 Olive Creek Mines, owmed and operated by Carl Parker, moved From Little Eva Creek in the Fairbanks District in 1962 and resumed operations on Olive Creek in the Tolovana District. Two non-contiguous $K_{x} q^{9-10}$ blocks of ground on the right-limit bench of olive Creek were mined during the season. Two D-8 tractors were used for mining, stripping, and stacking tailing; the dragline usually used for stacking tailing by this operator had not yet been moved from little Eva Creek. At the time of my visit, mining was not in progress; Carl and one employee were 
stripoing with the tractors, and one other employee was freighting $4 \times 4^{-1.53} 8$ ? equipment in from Littl.e Eva. Creek. Garl has acquired ground on Aray Creek, tributary to Livengood Creek, and he plans to mine there in 3.963.

B en Falls did not stuice any ground during 1962 but was $k_{x} 49$ - 4 reported to be working intermittently on his clains on :Iilbur Creek.

College, Alaska

irarch, 1963 liobort f. Saunders

State lining Lngineer 


\section{0}

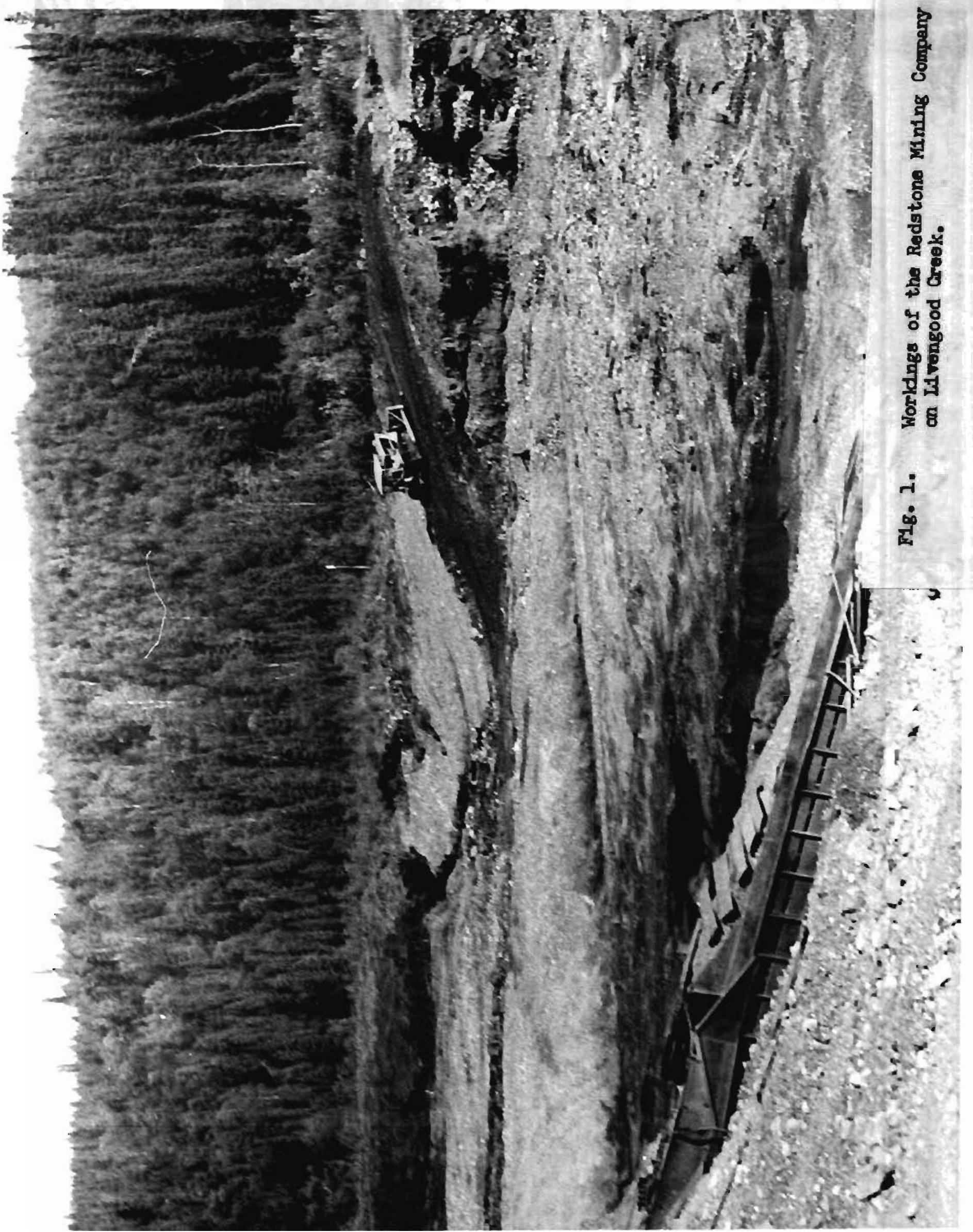




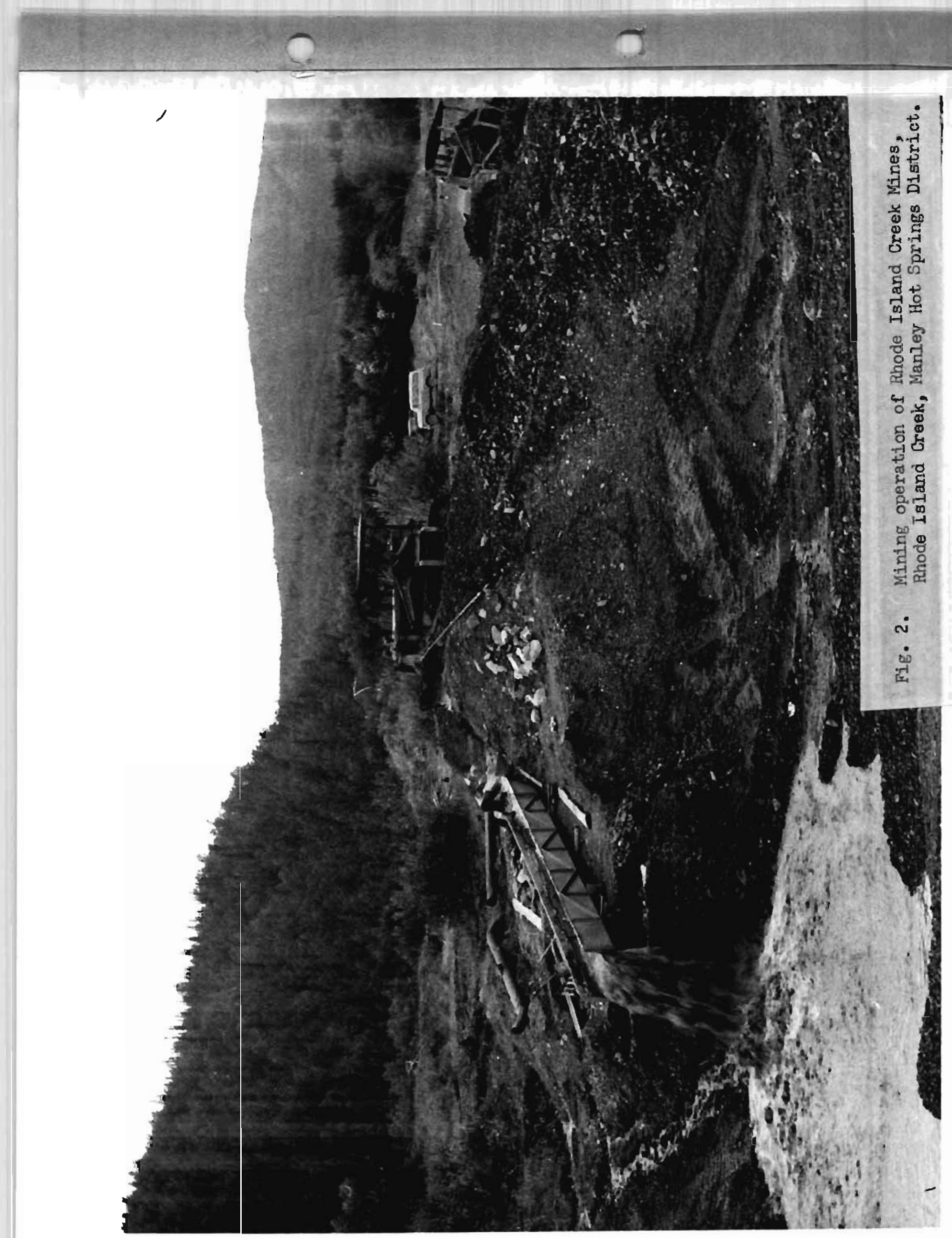

